ZOLTAN J. TOTH

\title{
The Public Opinion about the Death Penalty in Hungary and Worldwide: What Do Polls on Capital Punishment Show?
}

\author{
Submitted: 24.07.2020. Accepted: 10.09.2020
}

\begin{abstract}
A number of representative polls have been conducted on the death penalty in recent decades. There were some surveys whose authors were interested not only in the percentage of supporters and opponents of the death penalty, but also in whether this rate varies in different strata of society. Several polls were conducted, in which, in addition to socio-cultural factors, respondents were asked about their general attitudes and some research was also conducted in order to uncover the reasons behind the responses of the interviewees. From all of this, one can gain a clear picture as regards the socio-cultural characteristics of people in general, who are more in favour of the death penalty, as well as regarding what general attitudes respondents have and for what reasons they formed their views. The subsequent presentation of the Hungarian surveys will help one to see whether distance in time affects the perception of the social need for capital punishment, and how such need changes over time. Overall, the aim of this study is to present a comprehensive human approach to the death penalty; that is, the goal is not to examine how many people have supported or opposed the death penalty in a particular country in a given period of time, but to find out what factors influence commitment to or against capital punishment and the causes thereof, and what factors can change people's attitudes towards the death penalty.
\end{abstract}

Keywords: death penalty, public opinion, American polls, Hungary, reasons behind attitudes towards capital punishment.

1 Prof. Zoltan J. Toth - Department of Jurisprudence, Legal History and Church Law, Faculty of Law at Karoli Gaspar University of the Reformed Church in Hungary; e-mail: toth.zoltan@kre.hu; ORCID: 0000-0002-8836-7231.

2 This research was financed by Hungarian Academy of Sciences. 


\section{ZOLTAN J. TOTH}

\section{Kara śmierci w opinii publicznej na Węgrzech i na świecie: wnioski płynące z sondaży na temat kary śmierci}

Złożony do redakcji: 24.07.2020. Zaakceptowany do druku: 10.09.2020

\section{Streszczenie}

W ciągu ostatnich dziesięcioleci przeprowadzono wiele istotnych sondaży na temat kary śmierci. Niektóre z tych sondaży nie tylko badały rozkład opinii za karą śmierci i przeciw karze śmierci $w$ danych społeczeństwach $w$ danym czasie, lecz także analizowały trend rozkładu tych opinii w różnych warstwach społecznych. Przeprowadzono kilka sondaży, gdzie nie tylko skupiano się na czynnikach społeczno-kulturowych, ale też pytano respondentów o ich światopogląd ogółem. Badano również czynniki przekładające się na udzielanie danych odpowiedzi. Wyniki rzeczonych sondaży i badań rysują jasny obraz ogólnej społeczno-kulturowej natury osób popierających karę śmierci, a także dają wgląd w ogólne postawy respondentów względem czynników determinujących ich poglądy. Następujące $\mathrm{w}$ dalszej części omówienie sondaży przeprowadzonych na Węgrzech rzuca światło na kwestię wpływu upływu czasu na społeczny odbiór zasadności stosowania kary śmierci, a także opisuje zachodzące na przestrzeni lat zmiany w społecznym postrzeganiu zasadności stosowania tego rodzaju kary. Niniejsze opracowanie ma na celu przedstawić i omówić złożoność stosunku jednostki i zbiorowości ludzkiej do kary śmierci, w kontekście poszczególnych krajów i kultur. Nie chodzi tu jednak o analizę liczbową, o określenie liczby osób popierających karę śmierci lub będących przeciwko niej w danym kraju i w danym czasie, a raczej o rozpoznanie czynników kształtujących zbadane postawy i poglądy względem kary śmierci oraz czynników będących w stanie te postawy i poglądy zmienić.

Słowa kluczowe: kara śmierci, opinia publiczna, sondaże amerykańskie, Węgry, czynniki kształtujące postawę względem kary śmierci. 


\section{Introduction}

The issue of capital punishment is one of the most controversial topics on which the majority of people have a definite opinion. Although maintaining, abolishing or reinstating the death penalty is usually a political decision, there should also be a professional discourse on which such political decision can be based, which is a decision not be transferred directly to the people. Yet, due to the nature of the problem, the need to know the will and opinion of the people is legitimate. To this end, a number of surveys have been conducted, which have attempted, sometimes superficially, sometimes in detail, to determine what proportion of people supports the institution of the death penalty and what part of them opposes it, and whether there are significant differences in attitudes towards this legal institution between different groups in society (defined from different perspectives). Some surveys have gone so far as to try to uncover the reasons behind people's attitudes: that is, why they take their stand, and whether they oppose or support capital punishment.

Although, as mentioned, public opinion is not a conclusive argument for the state to develop regulations which are in line with the needs of society, it is nevertheless important to find out what attitudes towards crime in society exist, and which attitudes are significantly correlated with support for or opposition to the death penalty.

The present paper, in its first section, introduces important (mainly, but not exclusively, American) surveys on attitudes towards the death penalty, with particular emphasis on divergent opinions arising from the socio-cultural differences in society; that is, one looks at whether there is a difference between social groups in terms of support for capital punishment, and if so, in what direction and to what extent. Then one looks at the general attitudes with which support for or opposition to the death penalty can correlate. In the next chapter, the reasons why people become proponents or opponents of capital punishment, as well as the motivations for taking their position, are reviewed.

Finally, we turn to the case of Hungary, where several representative surveys have been conducted since the abolition of capital punishment in 1990. The examination of researches carried out at different times can make it clear how support for the death penalty changes over time: the number of pro-death penalty respondents is slowly declining (with small fluctuations) after the abolition of the death penalty, while the number of opponents of the death penalty is slowly (but definitely) in- 
creasing. It therefore seems plausible to conclude that the system of attitudes towards the death penalty depends on the extent to which society is aware of this sanction as a living legal institution.

Thus, the hypothesis that people are not necessarily proponents of the death penalty, but rather of tradition, seems correct: where the death penalty has long ceased to exist, that is, where people cannot recall this sanction as a legitimate, applicable legal consequence, they are less supportive of the death penalty; while where the memory of the death penalty is alive (i.e. where capital punishment is part of the legal system or has only been recently abolished), people are much more accustomed to the existence of the death penalty and much more supportive of its retention. All of this is not only scientifically interesting, but can also be taken into account in the development of legal policy concepts and in political decision-making.

\section{Socio-Demographic and Socio-Cultural Data}

In a timeline data analysis based on results of surveys performed by Gallup between 1936-1971 and in 1981, as well as on NORC's General Social Surveys in 1972-1978, 1980 and 1982-1991, Ellsworth and Gross found that men in each year supported capital punishment in a greater proportion than women, i.e. by about $4-5$ percentage points on average. This same study revealed that suburban residents supported the death penalty more than city or county residents.

Lifton and Mitchell quote an ABC News poll conducted in January 2000 in the course of which they assessed that the gap between the males and females was growing in those years, since, according to this ABC News survey, 73\% of men favoured capital punishment, while such support amounted to only $56 \%$ amongst women.

Robert M. Bohn analysed 21 of those 24 Gallup surveys conducted between 1936 and 1986 in which the company measured people's attitude towards the death penalty. These questionnaires also covered the main socio-demographic and socio-economic factors of the respondents, therefore, a conclusion can be drawn from the collected data on whether these attributes affect the attitude towards capital punishment or not, and if they do, to what extent. Concerning the age of respondents, Bohm found a notable difference in gender, age and income groups. As regards gender, data were provided by 21 Gallup polls. In these 21 surveys, $65 \%$ of males favoured capital punishment and so did only $53 \%$ of females, while, in contrast, $37 \%$ of women and $29 \%$ of men opposed to the death penalty. (The question remained unanswered by $8 \%$ of men and $11 \%$ of women.) Besides, concerning the support for capital punishment, the greatest difference between men and women was 
shown in 1965 (17 percentage points), and the smallest difference was observed in November 1985 (5 percentage points).

Bohm's analysis also revealed that the percentage of people in high-income groups who favour capital punishment exceeds the percentage of people in low-income groups. In the timeline reviewed by Bohm, 19 polls contained data for the income status of respondents. In the top category, $64 \%$ of the respondents agreed with the death penalty and 30\% did not, whilst in the bottom category, $50 \%$ supported capital punishment and 39\% did not. The largest difference between the rich and the poor was shown in November 1972 (23 percentage points), and the smallest difference was revealed in 1936 (4 percentage points).

The variable of age was available in 20 surveys of the analysed 21, but resulted in only insignificant differences. According to Bohm's calculation, $57 \%$ of respondents under the age of 30 favoured capital punishment, and so did $60 \%$ of the members of the age group of $30-49$ years, and, again, $60 \%$ of people in the age group of 50 years and over. These data are not eligible for drawing any sound conclusion, however, if one breaks down this time series of 20 polls, it becomes suitable to establish some kind of conclusion. According to Bohm, 'until 1960, people under 30 were more likely to favour and less likely to oppose the death penalty than people aged 50 and over. (...) After 1960, the trend reversed and, since then, people over 50 have been more likely to support and less likely to oppose the death penalty than people under 30.'

As for the other results, Bohm found that $58 \%, 61 \%$ and $55 \%$ of college graduates, high school graduates and primary school graduates, respectively, supported the death penalty; it was also shown that metropolitan residents were a little more likely to favour it than those living in smaller cities or villages. The precise data of the latter finding are as follows: $61 \%$ of people living in cities with over 1,000,000 inhabitants supported the death penalty, while only $55-56 \%$ of the respondents living in smaller settlements favoured it. However, among the latter category, there were no notable differences between people in different types of subcategories. That is, of people living in cities with 500,000-999,999 inhabitants, $56 \%$ were proponents of capital punishment; of those people living in cities with 2,500-499,999 inhabitants, $55 \%$ were proponents thereof; and of those respondents who lived in villages at the time of conducting the poll, that is, in settlements with under 2,500 inhabitants, $56 \%$ favoured capital punishment.

In Vidmar's research, the fact of favouring capital punishment correlated, though not significantly, with education, that is, it was slightly more probable for better educated people to support capital punishment than for those less educated. However, this poll was not able to detect any relationship between death penalty attitudes, on the one hand, and, on the other hand, gender, occupation, frequency 
of church attendance, family income, and some other, non-relevant socio-demographic variables.

In a non-representative survey, Midgley conducted research in the Republic of South Africa on the public opinion about capital punishment during the apartheid era, in 1971 . He found that while altogether $59.6 \%$ of the respondents were in favour of the death penalty and $40.4 \%$ were in opposition thereto, only slightly more than half of the male interviewees supported capital punishment, but so did about two thirds of the female respondents. He also found that the older a respondent is, on average, the more likely it is for him or her to support capital punishment. According to the data extracted from this survey, ' 60 per cent of the under 20 s were in favour of abolition but only 35 per cent of the over-60s favoured abolition.' As to the education, highly educated people, that is, those having graduated from colleges or universities, tended to be more reluctant to capital punishment, as only $35 \%$ of them supported it; the least educated people (those having completed only elementary school or no school at all) favoured capital punishment in a proportion of 60\%; and the averagely educated people having passed a final exam in a secondary school supported the practical application of this kind of legal sanction in a ratio as high as $70 \%$. In the end, as for the professional occupation, almost all, precisely $87 \%$ of entrepreneurs and most $(71 \%)$ of white-collar workers supported capital punishment, while 'respondents in professions (...) were overwhelmingly in favour of abolition.'

As for the differences concerning gender, the Harris surveys also strengthen the finding that women believe in capital punishment in a lower proportion than men do. For instance, in 1973, 59\% of the respondents favoured and 31\% opposed to the death penalty in itself; but when it comes to questions whether he or she would support capital punishment if it could be proved that it was not more effective than long prison sentences in keeping other people from committing crimes such as murder, at a national level, only 35\% answered that they would favour it and $48 \%$ replied that they would oppose to it. However, breaking down those results, the support for this legal sanction in the said situation amongst men was as high as $40 \%$, and only $31 \%$ amongst women, while the opposition was $48 \%$ at a national level, but only $44 \%$ amongst men and 53\% amongst women. Similarly, the raw results about judgement on capital punishment polled in 1997 showed that more males than females support capital punishment: altogether a majority of $75 \%$ favoured this sanction and only $22 \%$ objected to it; however, amongst males, the support for it reached the ratio of $80 \%$, while amongst females, it was only $71 \%$ (and the opposition was $19 \%$ and $25 \%$, respectively). In a recent, 2015 poll, the national support was $61 \%$, where $56 \%$ of women and $65 \%$ of men were in favour of the death penalty. The same survey tried to reveal a more latent attitude towards capital 
punishment with the question 'Which do you think is the appropriate sentence for Timothy McVeigh, who has been convicted of the Oklahoma City bombing, the death penalty or a life imprisonment which really is for life?' Of all the respondents, $64 \%$ answered 'death penalty', while such ratio was $67 \%$ amongst men and only $61 \%$ amongst women. In 1999, the Harris Poll inquired about the mean estimate of how many are innocent of those people convicted of murder; the greater objection of women to capital punishment was also revealed here since such mean estimate assessed by women was much higher (13\%) than that assessed by men (8\%). (In 2001 , this ratio was $14 \%$ and $9 \%$, respectively, and in 2008, the findings showed $14 \%$ and $10 \%$, respectively.)

As for education, the 1973 Harris Poll revealed that better educated people support capital punishment less in a pragmatic sense than more educated persons. That is, while at a national level $35 \%$ would favour capital punishment, even if there were evidence for impropriety in deterrence (and $48 \%$ would object to it in this case), only $32 \%$ of those with at least a college degree would favour it (and as many as $59 \%$ of them would object thereto). In contrast to this, $36 \%$ of those having completed only primary school would believe in capital punishment in the said case, and only $40 \%$ would not. More than forty years later, in the 2015 Harris Poll, $61 \%$ of the respondents favoured capital punishment, but among college graduates, this proportion was only $56 \%$, and it was $50 \%$ among postgraduates, whilst among those with graduated from high school or had lower levels of education, the ratio of supporters was as high as $65 \%$.

In the research of Bohm, Flanagan and Harris, conducted in New York in 1989 with a sample of 500 respondents, a slight difference appeared between men's and women's attitudes towards the death penalty. While $72 \%$ of all the interviewees supported capital punishment and $22 \%$ opposed it, $74 \%$ of males supported it and only $19 \%$ disfavoured it. Conversely, $71 \%$ of females favoured this kind of legal consequence for murderers, and as many as $25 \%$ of women opposed it. As for education, greater differences have been shown to exist. Among those who were at least high school graduates, only $69 \%$ supported capital punishment and $26 \%$ objected to it, whilst among those with lower levels of education, as high as $76 \%$ favoured such punishment and only $18 \%$ opposed it.

Fox, Radelet and Bonsteel analysed the National Opinion Research Center's cumulative General Social Surveys between 1972 and 1988, which concerned the public opinion about capital punishment. They found that, on average, men favour it more than women do since, in all of the years examined, the extent to which males supported the death penalty exceeded the ratio to which women did so. The gap between men and women relating to the acceptance of capital punishment was at least 5 percentage points (in 1987) and 14 percentage points at most (in 1972), while 
the mean difference appeared to be about 10 percentage points. As for age, incoherent results have been shown. That is, in the first few years (in 1972-1978), older people (aged 50 and over) definitely tended to be more supportive of capital punishment than younger respondents: the mean difference in these years was approximately 10 percentage points. Thereafter, however, this gap was eliminated, and the significance disappeared (and, what is more, in 1983 and 1984, the proportion of young people favouring death penalty outstripped that of elder people in support thereof). Similarly, as to the level of an educational degree, incoherent findings were revealed. Interestingly, no linear relationship in terms of educational attainment can be shown, that is, moderately educated people (those who graduated from high school) favour the death penalty at the greatest proportion, the most qualified people (with at least a bachelor's degree) do so in a lesser ratio, and the least qualified respondents (without any high school degree) do so to the least extent. Nevertheless, there are no significant differences between members of lower and upper classes, but there is a difference between members of higher and lower income groups: people with higher incomes tend to be more supportive of capital punishment than respondents with lower wages.

In Australia, Kelley and Braithwaite also found, on the basis of a sample consisting of 3,012 interviewees, that men are about 4 percentage points more likely to favour the death penalty than women, albeit women are more supportive of harsher sentences for criminals in general. (This finding, according to Kelley and Braithwaite, should be a subject of further research studies.) Apart from this, they concluded that age has no relevance as regards attitudes towards capital punishment, and this is also true for one's place of residence as well. The level of education, however, affects both general punitiveness and support for capital punishment, that is, less educated persons are more likely to propose both stiffer criminal sentences and capital punishment than better educated ones. According to Kelley and Braithwaite, 'each additional year of education reduces support [for the death penalty] by around 2 percent.' Similarly, one's occupational status (which is probably in connection with the level of education) also impacts the attitude towards this legal institution.

In a cross-national analysis comprising of 17,725 respondents of seventeen nations, Stack concluded that, measured as a binary variable, males were $9 \%$ more likely to support capital punishment than females were.

In a more recent Gallup survey conducted in 2004, $66 \%$ of the interviewees were in favour of capital punishment and 30\% were in opposition thereto. Meanwhile, based on aggregated data collected from 2001 until 2004, as many as $74 \%$ of men and only $62 \%$ of women supported the death penalty, and, conversely, as many as $32 \%$ of females and only $23 \%$ of male respondents objected to it. There was, however, 
no notable difference between various groups of age : among those 65 years or older, between 50-64 years, between 30-49 years and between 18-29 years, the ratio of the supporters of the death penalty were $65 \%, 68 \%, 68 \%$ and $69 \%$, respectively. In the end, the variable of church attendance did not show significant differences, either. $71 \%$ of those who never or rarely attended services answered that they favoured capital punishment; $69 \%$ of those who attended church approximately monthly supported the application of this legal sanction; and 65\% of regular churchgoers, that is, who attended church at least on a weekly basis or so, answered the question similarly.

\section{The Relationship Between Attitudes Towards Capital Punishment and General Attitudes}

According to Comrey and Newmeyer, supporting capital punishment was positively related to the attitude of conservativism.

Vidmar found a positive correlation between supporting capital punishment and the intensity of favouring retribution towards criminals in general. His survey revealed that the more somebody favours the death penalty, the higher scores he or she gets on the retribution index. The results also show that those who supported the death penalty were more likely to support punishment (not on criminals, but in general) than those opposed to that. However, he did not find a statistically significant relationship between a subjective sense of being threatened by crime and the extent of supporting the death penalty. Although more proponents of capital punishment tended to believe that crime was increasing than opponents of the death penalty, and people in the former group were more likely to report having been a victim of a crime than respondents in the latter group, the two main variables (i.e. whether they feel they could be a victim of a crime in the future and whether they were threatened by crimes in the past) did not indicate any correlation. That is, as per Vidmar, 'the hypothesis of a relationship between perceived threat and support for capital punishment received only equivocal support.' In the end, Vidmar found in a Chi-square analysis that the intensity of favouring capital punishment was positively correlated with the aptitude to conservativism and authoritarianism.

However, Thomas and Foster criticise the appropriateness of these findings, stating that these conclusions are, probably, deriving from their makers' presuppositions and not corroborated by strong empirical evidence. As for Thomas and Foster's own conceptualisation of public favour of capital punishment, they set up five variables (perception of the crime rate, fear of victimisation, perception of the 
effectiveness of punishment, willingness to employ punishment, and support for capital punishment), and attempted to find out what kind of linkages are among any two or three of them. As for the correlation between capital punishment and the first four variables, they revealed that the most explanatory relationship stands between the willingness to employ punishment and the support for capital punishment, and the second most important factor is the belief in the deterrent effect of criminal sanctions imposed, or imposable, on perpetrators, while ' $[t]$ he individual contribution of the remaining two variables is minimal, though they do appear to be important determinants of perceived effectiveness of punishment and willingness to employ punishment.' As a conclusion, they claim that perceptions of rising crime rates induces extended distress due to fear of the greater possibility for anybody to be a victim of a crime. This is 'directly linked to both increased valuations of the effectiveness of punishment and willingness to employ punishment as a response to criminal offenders,' and 'increased valuations of the effectiveness of punishment are, in turn, directly linked to both heightened willingness to employ punishment and increased levels of support for capital punishment.'

Kelley and Braithwaite found a correlation in their study conducted in Australia between hostility to out-groups (especially to non-English migrants) and support for capital punishment. They also revealed that those tend to have a pessimistic view of human nature, that is, those who do not believe in the corrigibility thereof, are more feasible to support this kind of legal institution than those who hope that criminals might develop themselves. They have, however, found, that neither fear of crime nor religious belief has any effect on support for or opposition to capital punishment, but the impact of mass media on people does have such an effect on attitudes towards capital punishment.

\section{Rationales of Proposing or Opposing Capital Punishment}

In Canada, Gallup carried out an opinion poll in 1972, in which it attempted to find out what kind of reasons drives proponents and opponents of capital punishment to be in favour of the death penalty or to be opposed thereto. The survey found that $64 \%$ of those favouring the death penalty deemed it had a deterrent effect, $4 \%$ answered that this sanction could save costs and $7 \%$ claimed that it had an incapacitation effect, that is, it could eliminate the possibility of recidivism. This means that three quarters of the supporting interviewees altogether were in favour of this kind of sanction because they felt it that had some kind of utilitarian value. In contrast to this, only $14 \%$ of the favouring respondents were of the opinion that it was a just a consequence to be imposed on those who murder someone else or 
commit other serious crimes, that is, only $14 \%$ supported this legal institution for retributive reasons.

To check the results of this Canadian Gallup poll, Vidmar conducted research of his own on a more sophisticated methodological basis in 1974. In the course of this opinion poll, Vidmar asked 144 English-Canadians to reply to a detailed questionnaire which attempted to measure not only the contingency of favouring or opposing respondents' demographic characteristics, but also their general and criminal attitudes (including retributiveness, punitiveness, and inclination to authoritarianism). As for the attitudes towards the death penalty, $78 \%$ of the respondents favoured such a form of punishment, partly or wholly, and $22 \%$ opposed thereto. The possible rationales of those who supported it somewhat and answered an open-ended question ('What are the reasons for your attitudes toward the death penalty?') were divided into 5 parts as follows: 'retribution, vengeance, or punishment' (32\%), 'deterrence' (42\%), 'when rehabilitation impossible' $(4 \%)$, 'cost' $(2 \%)$, 'retribution and deterrence' (2\%). Apart from these, $14 \%$ did not answer this question or their answers proved to be uncodeable. In case of another, forced-choice question of 'In your opinion which of the following is a more important reason for having the death penalty for murder?,' 63\% of the death penalty proponents answered on the ground of deterrence that was meant 'to serve as an example to other people and thus deter them from committing similar crimes' and only 33\% replied in the following way: 'to make the guilty person pay with his life for killing another person.' In the end, when these persons were asked 'If you could be convinced that the death penalty is no deterrent to murder, would you still favour it?', 55\% responded that he or she would support capital punishment even in the said case, and only $45 \%$ replied 'no'.

Ellsworth and Gross, on the basis of the ABC News and the Washington Post joint poll in 1981 and the Gallup polls in 1985 and 1991, analysed what kind of reasons determine people's attitudes towards capital punishment. They set up four categories of the possible causes behind the opinion of proponents, namely 'life for a life', general deterrence, incapacitation, and the cost of the other sanctions. Of these, the last three constitute a distinct and unitary category: the group of the 'utilitarian' arguments, as opposed to the first one, which can be denominated as a moral or deontological argument. They found that the most popular reason why one favours the death penalty is the moral one, that is, the retributive ground. As for the opponents of capital punishment, the solid ground for their attitude thereto is the same. They also oppose this sanction on the basis of moral grounds. (Their most common reasons were that it is 'wrong to take a life' or 'punishment should be left to God,' but not the possible discrimination or the possibility of miscarriages of justice.) 
Very similar conclusions were drawn by Oberwittler and Qi in a survey conducted among 4,472 Chinese respondents in face-to-face interviews. $78.1 \%$ of those interviewees who favoured the penalty of death agreed with the assertion, reflecting on the attitude to retribution, that people who take a life deserve to be punished by having their own life taken. As for deterrence, $63.6 \%$ agreed that the abolition of the death penalty would immediately cause an increase of crime in China, while incapacitation was qualified as a cause for support for capital punishment only among $46.5 \%$ of the respondents. This means that retribution is the most strongly favoured goal of the death penalty.

Sarat and Vidmar also concluded that a considerable part of pro-death penalty respondents favours this kind of legal sanction not because of its practical usefulness, but strictly on moral, retributive grounds. After presenting information about the practice of capital punishment to those having been in favour of the death penalty, they found that only $40 \%$ of them changed their attitude, but $60 \%$ of them did not. The main cause of such a phenomenon, according to Sarat and Vidmar, is that 'initial support for it is grounded in a desire for vengeance and retribution against those who commit capital crimes.'

However, from the results of the Harris polls conducted in 1973, contrary conclusions can be drawn. In the 1973 Harris poll showed that $61 \%$ of the respondents acknowledged the view that 'capital punishment is more effective than other penalties in keeping people from committing crimes,' and 40-41\% made the assertion that it is a just sentence for murder, though, if it was be proven unsatisfactory in deterring potential criminals, only $35 \%$ of the interviewees would favour it and $48 \%$ would oppose it.

Similarly, a study of Bohm, Flanagan and Harris also resulted in that the deterrent effect has a meaningful impact on death penalty attitudes. The researchers found that when asked how they would react if new evidence showed that capital punishment does not lower the murder rate, $54 \%$ of the respondents answered that they would cease to support capital punishment, and only $46 \%$ would continue supporting it in the absence of a deterrent effect.

A potential resolution of this apparent contradiction may be the difference between real attitudes and surface arguments: according to Vidmar and Ellsworth, an 'expressed belief in deterrent efficacy may be seen by proponents as the most socially acceptable justification for favouring the death penalty, and thus may be used as a cover for other, less acceptable reasons.'

As for the relationship between retributive and utilitarian sentiments, Thomas, in a survey performed in Virginia between 1973 and 1974 with 3,334 respondents, found a strong correlation, that is, on the one hand, retributive persons tended to embrace practical beliefs supporting capital punishment, and on the other hand, 
believers in death penalty's efficacy are much more likely to perceive this legal institution as just a consequence to be imposed on those having committed more serious crimes than others. He also concluded that, separating the two sentiments from each other, there was only a moderate relationship between retributive beliefs and support of the death penalty, while there was a stronger relationship between utilitarian sentiments and favour of capital punishment. The results also showed that 'although the independent impact of retributive beliefs on support for capital punishment is relatively weak, the independent effect of utilitarian beliefs is substantial,' that is, in other words, 'retributive beliefs do correlate with a willingness to support the death penalty, but only when these notions of just punishment are bolstered by the complementary belief that the imposition of the death penalty will serve what they view as a useful purpose.'

In a Gallup poll conducted on 12-15 October 2014, pro-death penalty respondents had to answer the open-ended question: 'Why do you favour the death penalty for persons convicted of murder?,' while those who objected to it had to reply to the question: 'Why do you oppose the death penalty for persons convicted of murder?' In both cases, the deontological point of view appeared to be more important than the utilitarian one. As for the former argument, proponents of capital punishment tended to support this legal institution on moral, that is, retributive grounds: about $60 \%$ answered that they were in favour thereof because of some kind of deontological reasons. In contrast to this, only $32 \%$ supported capital punishment due to utilitarian arguments. Similarly, the majority (57\%) of opponents of capital punishment opposed it on deontological grounds and only a small part $(28 \%)$ of them did it for utilitarian reasons.

\section{Public Opinion on Capital Punishment in Hungary}

After the abolition of capital punishment by the decision 23/1990. (31 October) AB of the Constitutional Court, several nation-wide representative surveys were conducted in Hungary on the public opinion regarding this legal sanction. The first one was made by Szonda Ipsos right after the publication of the Constitutional Court's decision in 1991. It concluded that $77.2 \%$ of adult Hungarian population opposed the abolition of capital punishment, which means that more than three-quarters of people supported capital punishment. Only 20.4\% supported abolition (which means that only one-fifth of Hungarians opposed capital punishment), and 2.4\% did not answer.

In 2001, the TÁRKI Institute made another survey about this issue; according to the results, in the first year of the third millennium, $68 \%$ of the Hungarian 
population would agree with the application of capital punishment. (This data was collected within the Central European Opinion Research Group - CEORG, and the same question was asked at the same time in the Czech Republic, Poland and Lithuania, which allowed for the comparison of the results. On the basis of this, it may be concluded that the Hungarian attitude about capital punishment can be deemed general in the region because even though only $58 \%$ of the Czech agreed with the possible restoration of capital punishment, $76 \%$ of Lithuanians and $72 \%$ of the Polish supported it.) This survey also concluded that there is a reverse proportionality between the support of capital punishment and satisfaction with public safety and work of the police, which means that the safer one feels, the less one supports the maintenance or restoration of capital punishment.

The third survey was made in March 2005 when Medián Public Opinion and Market Research Institute measured the opinion of the population about capital punishment on a representative sample of 1,200 people. According to this, two-thirds of Hungarians definitely supported capital punishment: $63 \%$ would consider it acceptable even in peacetime, whereas $7 \%$ would not allow it during a time of peace, but in wartime only. Only $28 \%$ said that they would not accept it at all, and $2 \%$ could not or did not want to answer. The next representative survey was also made by Medián upon the request of HVG, a popular weekly, between 3-7 December 2010 on a sample of 1,200 people. To the question 'Would you rather support or rather oppose the application of capital punishment for serious crimes?,' 69\% replied 'rather yes', 27\% replied 'rather no', while 4\% could not answer.

In December 2015, Szonda-Ipsos again conducted a large-scale survey in Hungary on a representative sample of 1,000 people. István H. Szilágyi and György Gajduschek re-analysed the data of this survey in 2017 in order to determine the attitude towards crime in Hungary. This was the most thorough investigation in Hungary related to this matter in the past few decades, and it resulted in the most detailed data. H. Szilágyi and Gajduschek asked a four-item question regarding capital punishment in this questionnaire. The respondents had to choose between model answers, of which two were in support of, and two were in opposition to the death penalty, while also asking the respondent to give the basic reasons for his or her opinion. This allowed interviewees to choose answers as regards why they support the death penalty or why they oppose it and, in both cases, for what reasons. Two reasons were provided for this: utilitarian or moral. The respondents had to choose one assertion from the following statements that they considered most appropriate and closest to their views. 1) The death penalty is meaningless because it has no deterrent effect. 2) The death penalty is unacceptable because the state has no right to kill anyone. 3) The death penalty should be reinstated, as this would be the fairest punishment for the most serious crimes. 4) The death penalty should 
be reinstated, as it would protect society from incurable criminals. $13.2 \%$ of respondents opted for the first statement, while $26.7 \%$ opted for the second, which is approximately $40 \%$ (39.9\% to be exact) in favour of the abolitionist position. Compared to this, $31.5 \%$ of the respondents voted in favour of the third assertion and $23.8 \%$ voted in favour of the fourth, meaning that about $55 \%$ in total $(55.3 \%$ to be exact) proved to be proponents of capital punishment. (48 persons, i.e. $4.8 \%$ of respondents were unable or unwilling to answer.)

Interestingly, looking at the reasons chosen for the answers, it can be seen that $37 \%$ formed their opinions on pragmatic-utilitarian, and 58\% on deontological-ethical grounds (either pro or con). Thus, in terms of the attitude towards the death penalty in Hungary, there is a slight majority of respondents who express their views on a theoretical, moral basis, and a minority of those who form their views on a utilitarian ground. H. Szilágyi and Gajduschek also found that neither gender nor age plays a role in what one thinks of the death penalty (which is somewhat surprising, according to a large number of US surveys to the contrary), but that income (and, one might add, presumably school education which might correlate with the level of income) already has an explanatory role: the higher one's income (and most likely his or her educational background) is, the less likely he or she is to support the death penalty.

The last survey was conducted specifically for scientific research, led by László Kelemen, carried out in November and December 2018, also on a representative sample of one thousand people. The results of this survey are very similar to those of H. Szilágyi and Gajduschek. Kelemen used the same items of questions and model answers as H. Szilágyi and Gajduschek. $18 \%$ chose that death penalty is meaningless because it has no deterrent effect. $22 \%$ thought that death penalty is unacceptable because the state has no right to kill someone. 30\% believed that the death penalty should be reinstated because this would be the fairest punishment for the most serious crimes; and 24\% thought that the death penalty should be reinstated because it would protect society from incurable criminals. Overall, $40 \%$ of those surveyed were abolitionists and $54 \%$ were in favour of the death penalty ( $6 \%$ of interviewees did not answer).

There was a significant difference between the respondents in terms of gender and highest level of education. While $58 \%$ of the men who substantively responded to the question said that death penalty should be reinstated, only $50 \%$ of women thought so. The difference is even more spectacular in terms of educational attainment: of those who have not completed elementary school, of those who have completed it, but have not completed their profession or their baccalaureate, and of those who have completed high school (but not college or university), 57\%, 55\% 
and $56 \%$, respectively, supported capital punishment. This proportion, however, was only $42 \%$ among college graduates and only $38 \%$ among university graduates.

It may be seen from all these figures that the Hungarian public has always been in favour of the most severe criminal sanction, even though the rate of support has been slowly but steadily declining since the early nineties, and today just over half of the Hungarian people advocate the reinstatement of capital punishment.

\section{Conclusions}

On the basis of the presented and analysed data, some general characteristics can be formulated in relation to the attitude towards the death penalty.

Perhaps the most important lesson (and this is best shown by the analysis of the Hungarian data sets) is that pro- or anti-death penalty stance is not an unchangeable social endowment, but a product of the legal environment and social perception and, as such, a time-varying feature. So when it comes to whether the death penalty needs to be regulated in a particular state (even if assuming that the decision to do so is based on social support for the death penalty), one must not forget that the attitude towards capital punishment exists in one's consciousness and is greatly influenced by the existing situation, current experience, and recent memories. The more vivid the memory of members of society about the death penalty is, the more nostalgic the way people think of it will be; in contrast, the more the memories of society have faded (perhaps the death penalty only forms part of the legal history), the less real need will emerge in such regard.

It is also interesting to see what socio-cultural characteristics those who support the death penalty have. In this regard, it is worth noting that, according to virtually all surveys, men are more supportive of the death penalty than women, which may be due to either educational causes or the nature of men's psyche. According to most opinion polls, the richer are also more in favour of retribution than the poor, which may be due to the fact that the majority of violent perpetrators tend to come from the poorer strata of society (poverty and the associated deviance, such as alcohol dependence, are criminogenic factors), so there may be more potential perpetrators among the acquaintances of the poor than among those of the richer. (Conversely, however, this is not the case because experience has shown that the victims of perpetrators who come from a lower segment of society are also from a lower segment thereof.)

There is a strong correlation between education and the attitude towards retaliation: the more educated someone is, the less likely he or she is to support capital 
punishment. No such general relationship can be observed, however, as regards the last major socio-cultural factor: age. In terms of age, no such general correlation can be shown; some surveys find that younger people are more in favour of the death penalty, other researches result in that older people reveal a more pro-retribution stance (and there are also studies showing that middle-aged people are more likely to be defenders of capital punishment).

Certain characteristics and attitudes also correlate with the support for the death penalty. Thus, for instance, conservatives tend to wish for a tougher penal policy than liberals. Related to this is the position of parties: support for the death penalty is higher among voters for right-wing parties than among voters for left-wing ones. (Furthermore, religiosity also plays a role in the development of opinions, but this latter effect may be only indirect, that is, it might affect one's stance through conservatism or party choice alone, and not in itself as a determinative factor.) The most interesting factor, however, would certainly be the reason why respondents form a particular position in the matter of capital punishment. Unfortunately, the survey data is incoherent in this regard, so one does not know exactly whether the decision on proposing or opposing the death penalty is made on a moral or, rather, a more pragmatic basis. However, on the basis on the different results of each survey, one can say that both support for and opposition to capital punishment can have almost equally theoretical and practical causes.

\section{Bibliography}

Bohm R.M., American Death Penalty Opinion, 1936-1986: A Critical Examination of the Gallup Polls, [in:] Bohm R.M. (ed.), The Death Penalty in America. Current Research, Cincinnati, KY 1991: 113-145.

Bohm R.M., Flanagan T.J., Harris Ph.W., Current Death Penalty Opinion in New York State, "Albany Law Review" 1989-1990, 54: 819-843.

Comrey A.L., Newmeyer J.A., Measurement of Radicalism-Conservativism, "The Journal of Social Psychology" 1965, 67: 357-369.

Donohue J.J., Wolfers J., Uses and Abuses of Empirical Evidence in the Death Penalty Debate, "Stanford Law Review" 2005-2006, 58: 791-845.

Ehrlich I., The Deterrent Effect of Capital Punishment. A Question of Life and Death, "American Economic Review" 1975, 6: 397-417.

Fagan J., Zimring F.E., Geller A., Capital Punishment and Capital Murder. Market Share and the Deterrent Effects of the Death Penalty, "Texas Law Review" 2005-2006, 84: 1803-1867. Firon A., Káinbélyeg. Nyugdijazzuk-e végleg a hóhért? [Mark of Cain. Shall We Retire the Hangman for Good?], Budapest 1991.

Fox J.A., Radelet M.L., Bonsteel J.L., Death Penalty Opinion in the Post-Furman Years, "New York University Review of Law \& Social Change" 1990-1991, 18: 499-528. 
Gibbs J.P., Preventive Effect of Capital Punishment Other Than Deterrence, [in:] H.A. Bedau, (ed.), The Death Penalty in America, Oxford 1982: 103-116.

Gross S.R., Ellsworth Ph.C., Hardening of the Attitudes. Americans' Views on the Death Penalty, "Journal of Social Issues" 1994, 50(2): 19-52.

Hann E., Lakatos Z., Nem kényszer, hanem... Felmérés az alkotmányozásról [Not a Compulsion, but... A Constitutional Survey], HVG 25.12.2010, 51-52: 14-16.

Szilágyi I.H., Gajduschek G., Nevelés és büntetés. A büntetési igény alakulása a magyar lakosság jogtudatában az újabb hazai empirikus kutatások fényében, különös tekintettel a nevelési elvek hatására [Education and Punishment. Evolution of the Need for Punishment in the Legal Consciousness of the Hungarian Population in the Light of Recent Hungarian Empirical Research, With special Regard to the Effect of Educational Principles], "MTA Law Working Papers", MTA/Hungarian Academy of Sciences 2017, 7.

Szilágyi I.H., Kelemen L., Miként vélekedünk a jogról? [How Do We Feel About the Law?], Budapest 2019.

Kelley J., Braithwaite J., Public Opinion and the Death Penalty in Australia, "Justice Quarterly" 1990, 7(3): 529-563.

Lifton R.J., Mitchell G., Who Owns Death? Capital Punishment, the American Conscience, and the End of Executions, Harper Perennial 2002.

Midgley J., Public Opinion and the Death Penalty in South Africa, "British Journal of Criminology" 1974, 14: 345-358.

Oberwittler D., Qi S., Public Opinion on the Death Penalty in China. Results from a General Population Survey Conducted in Three Provinces in 2007/08, "Max Planck Institute for Foreign and International Criminal Law" 2008.

Sarat A., Vidmar N., Public Opinion, the Death Penalty, and the Eighth Amendment. Testing the Marshall Hypothesis, "Wisconsin Law Review" 1976, 17: 171-206.

Sellin Th., Capital Punishment, "Federal Probation" 1961, 25: 3-11.

Shepherd J.M., Deterrence versus Brutalization. Capital Punishment's Differing Impacts Among States, "Michigan Law Review" 2005-2006, 104(2): 203-255.

Stack S., Public Opinion on the Death Penalty: Analysis of Individual-Level Data from 17 Nations, "International Criminal Justice Review" 2004, 14: 69-98.

Thomas Ch.W., Eighth Amendment Challenges to the Death Penalty. The Relevance of Informed Public Opinion, "Vanderbilt Law Review" 1977, 30: 1005-1030.

Thomas Ch.W., Foster S.C., A Sociological Perspective on Public Support for Capital Punishment, "American Journal of Orthopsychiatry" 1975, 45(2): 641-657.

Toth Z.J., Changing Attitudes Towards the Death Penalty. Hungary's Renewed Support for Capital Punishment, Cham, Switzerland 2020.

Toth Z.J., The Capital Punishment Controversy in Hungary. Fragments on the Issues of Deterrent Effect and Wrongful Convictions, "European Journal of Crime, Criminal Law and Criminal Justice" 2013, 21(1): 37-58.

Toth Z.J., The Contemporary Debate on Capital Punishment - With Special Regard to That in Hungary, "Krytyka Prawa” 2018, 10(3): 136-158. 
Toth Z.J., The Deterrent Effect of the Death Penalty - from an Econometric Point of View, "De iurisprudentia et iure publico" 2012, 1-2: 151-186.

Toth Z.J., The Right to Life and Human Dignity in Hungary Concerning the Issue of Capital Punishment, [in:] Constitutional Values in Contemporary Legal Space I (Collection of Research Papers in Conjunction with the 6th International Scientific Conference of the Faculty of Law of the University of Latvia, 16-17.11.2016), Riga 2016: 522-533.

Vidmar N., Retributive and Utilitarian Motives and Other Correlates of Canadian Attitudes Toward the Death Penalty, "The Canadian Psychologist" 1974, 15(4): 337-356.

Vidmar N., Ellsworth Ph., Public Opinion and the Death Penalty, "Stanford Law Review" 1973-1974, 26: 1245-1270. 